\title{
Endocrine disruptors in bottled mineral water: total estrogenic burden and migration from plastic bottles
}

\author{
Martin Wagner • Jörg Oehlmann
}

Received: 6 November 2008 / Accepted: 18 December 2008 /Published online: 10 March 2009

(C) The Author(s) 2009. This article is published with open access at Springerlink.com

\begin{abstract}
Background, aim, and scope Food consumption is an important route of human exposure to endocrine-disrupting chemicals. So far, this has been demonstrated by exposure modeling or analytical identification of single substances in foodstuff (e.g., phthalates) and human body fluids (e.g., urine and blood). Since the research in this field is focused on few chemicals (and thus missing mixture effects), the overall contamination of edibles with xenohormones is largely unknown. The aim of this study was to assess the integrated estrogenic burden of bottled mineral water as model foodstuff and to characterize the potential sources of the estrogenic contamination.

Materials, methods, and results In the present study, we analyzed commercially available mineral water in an in vitro system with the human estrogen receptor alpha and detected estrogenic contamination in $60 \%$ of all samples with a maximum activity equivalent to $75.2 \mathrm{ng} / \mathrm{l}$ of the natural sex hormone $17 \beta$-estradiol. Furthermore, breeding of the molluskan model Potamopyrgus antipodarum in water bottles made of glass and plastic [polyethylene terephthalate (PET)] resulted in an increased reproductive output of snails cultured in PET bottles. This provides first evidence that substances leaching from plastic food packaging materials act as functional estrogens in vivo.
\end{abstract}

Responsible editor: Markus Hecker

M. Wagner $(\bowtie) \cdot J$. Oehlmann

Department of Aquatic Ecotoxicology,

Johann Wolfgang Goethe University,

Siesmayerstr. $70 \mathrm{~A}$,

60054 Frankfurt am Main, Germany

e-mail: wagner@bio.uni-frankfurt.de
Discussion and conclusions Our results demonstrate a widespread contamination of mineral water with xenoestrogens that partly originates from compounds leaching from the plastic packaging material. These substances possess potent estrogenic activity in vivo in a molluskan sentinel. Overall, the results indicate that a broader range of foodstuff may be contaminated with endocrine disruptors when packed in plastics.

Keywords Endocrine disrupting chemicals .

Estradiol equivalents $\cdot$ Human exposure $\cdot$ In vitro effects . In vivo effects $\cdot$ Mineral water Plastic bottles .

Plastic packaging $\cdot$ Polyethylene terephthalate .

Potamopyrgus antipodarum . Yeast estrogen screen .

Xenoestrogens

\section{Background, aim, and scope}

With the publication of Theo Colborn's scientific best-seller Our stolen future (Colborn et al. 1996), endocrine disruption became a public, political, and scientific issue. Since then, the list of suspected endocrine disrupting chemicals (EDCs) has been steadily growing, and the research in this field has made substantial progress (Hotchkiss et al. 2008). However, the causality between the exposure to EDCs and adverse human health effects is still controversially discussed (Safe 2000, 2005; Sharpe 2003; Waring and Harris 2005) due to the multifactoral etiology of hormone-related diseases, although evidence for causality between exposure to xenohormones and developmental as well as reproductive disorders strengthens (Sharpe 2003). 
For instance, in utero exposure to phthalate plasticizers has been shown to be associated with a decreased anogenital distance in male infants indicating undervirilization induced by environmental levels of these endocrine disruptors (Swan et al. 2005). Vice versa, phthalate exposure to girls has claimed to be correlated with an earlier onset of puberty (Colón et al. 2000), an effect that has been experimentally verified in mice in the case of the plastic component bisphenol A as well (Howdeshell et al. 1999). Recently, the debate about endocrine disruption has been heated up by findings that some EDCs may exhibit epigenetic transgenerational effects (Anway et al. 2005).

Though many endocrine disruptors are ubiquitous in the environment and humans are known to be contaminated with a wide range of compounds (Damstra et al. 2002), exact routes of human exposure remain largely unknown (Damstra 2003; Schettler 2006; Sharpe 2003). Apparently there are various sources and pathways of xenohormone uptake: inhalation (i.e., from indoor air), dermal absorption (i.e., from personal care products), and ingestion of food. The contamination of foodstuff by production-related compounds has been documented analytically. Nonylphenols, as degradation products of commercial and industrial surfactants, for example, are identified ubiquitously in a broad variety of nourishments (Guenther et al. 2002).

Another source of xenobiotics in foodstuff is rarely taken into account when dealing with endocrine disruption: substances migrating from packaging material into edibles (Lau and Wong 2000). In order to optimize the properties of packaging materials (i.e., durability, elasticity, color), a variety of additives, such as stabilizers, antioxidants, coupling agents, and pigments, is used in the formulation. Especially additives from plastics (so-called plasticizers) are known to leach out of the packaging and consequently accumulate in the foodstuff (Biles et al. 1998; Casajuana and Lacorte 2003; Fankhauser-Noti et al. 2006; Mcneal et al. 2000; Zygoura et al. 2005). Given the fact that some of these compounds are known EDCs (i.e., bisphenol A, vom Saal and Hughes 2005), we hypothesize that the migration of substances from packaging material into foodstuff may contribute to human exposure with xenohormones.

In the current study, bottled mineral water serves as a model foodstuff because it is a simple matrix and it does not contain endogenous hormones, like for example dairy products. Moreover, consumption of mineral water is increasing worldwide (Montuori et al. 2008). On the German market, mineral water is available in two major sorts of packaging material: glass and PET (PETE, polyethylene terephthalate, resin identification code 1) bottles. Moreover, some brands of mineral water are sold in a packaging called Tetra Pak (Tetra Brick) although only to a minor extent. These paperboard boxes are coated with an inner plastic film and are more commonly used for packing milk and fruit juices.

\section{Materials and methods}

\subsection{Samples}

Twenty brands of mineral water (coded as A-O, nine bottled in glass and plastic each, two bottled in Tetra Pak) from different price segments were chosen either because of their high market shares or ratio of glass/PET use in Germany. The samples included mineral water from four producers (A-D) that were obtained both in glass and in PET bottles. For each brand, six mineral water bottles were purchased in local shops and stored under consumer relevant conditions (dark, $4{ }^{\circ} \mathrm{C}$ before analysis). Mineral water samples were taken from three bottles per brand and tested directly with the yeast estrogen screen (YES) in three independent experiments. A representative subset of four brands of glass bottles and six brands of plastic bottles (brands A-E) was chosen for the reproduction test with Potamopyrgus antipodarum (three bottles per brand).

\subsection{Yeast estrogen screen}

The yeast strain contains the stably transfected human estrogen receptor alpha $(\mathrm{hER} \alpha)$ gene and an expression plasmid containing the reporter gene lac $Z$ encoding $\beta$ galactosidase under the control of estrogen response elements (ERE). Upon receptor activation and ERE binding, $\beta$-galactosidase is expressed. The $\beta$-galactosidase activity is measured as the change in absorbance at $540 \mathrm{~nm}$ caused by cleavage of the chromogenic substrate chlorophenol red- $\beta$-D-galactopyranoside (CPRG).

Assay procedure and data analysis were conducted as described previously (Routledge and Sumpter 1996; Rutishauser et al. 2004), with several modifications to test water samples directly and to accelerate the sample throughput. Minimal medium was prepared by supplementing ultrapure water with $0.67 \% \mathrm{w} / \mathrm{v}$ yeast nitrogen base without amino acids, $2 \% w / v \mathrm{D}-(+)$-glucose, and the appropriate amino acids. Yeast cultures were grown overnight to log-phase.

Seventy-five microliters water sample were added to a 96-well microtiter plate in eight replicates. Preliminary experiments indicated that laboratory tap water was least contaminated and hence served as a negative control (eight replicates on each plate). Fivefold minimal medium was supplemented with $100 \mu \mathrm{M}$ copper(II)sulfate, $0.67 \mathrm{mg} / \mathrm{ml}$ ampicillin, and streptomycin. Twenty-five microliters medium (containing $1 \% v / v$ ethanol) were added to each well. A serial dilution of $17 \beta$-estradiol in fivefold medium (in $1 \% v / v$ ethanol, $3 \mathrm{pM}-100 \mathrm{nM}$ final concentration) served as a positive control (eight replicates per concentration in each experiment). Yeast cells from the log-phase culture were diluted 1:5 in fresh minimal medium, and $20 \mu \mathrm{l}$ of the cell suspension were added to each well. For blank values (eight 
replicates on one plate) medium was added instead of cells. The microtiter plates were sealed with a gas permeable membrane (Breathe-Easy, Diversified Biotech, Boston, MA, USA) to avoid cross contamination and were incubated for $24 \mathrm{~h}\left(30^{\circ} \mathrm{C}, 750 \mathrm{rpm}\right)$.

Relative cell density was determined by measuring optical density at $595 \mathrm{~nm}$. For $\beta$-galactosidase assay, buffer $\mathrm{Z}$ was supplemented with $40 \% \mathrm{w} / v \mathrm{CPRG}, 0.25 \% v / v \beta-$ mercaptoethanol, and $170 \mathrm{U} / \mathrm{ml}$ lyticase. One hundred microliters were added to each well. Optical density at $540 \mathrm{~nm}$ was determined in 30-min intervals over a period of $4 \mathrm{~h}$.

Optical densities were corrected according to blank values and relative cell density. For each time of measurement, dose-response relationship for $17 \beta$-estradiol was calculated using a four-parameter logistic function (Prism 5.0, GraphPad Software Inc., San Diego, CA, USA). To assure comparability of independent experiments, only those measurements were considered whose half maximal response $\left(\mathrm{EC}_{50}\right)$ was next to $1 \times 10^{-10} \mathrm{M} 17 \beta$-estradiol (range, $9 \times$ $10^{-11}$ to $2 \times 10^{-10} \mathrm{M}$ ) with a correlation coefficient $r^{2}>0.9$.

Estradiol equivalents (EEQ) of the water samples were calculated by inserting the corrected optical densities (corrected OD) in the inversion of the four parameter logistic function (Eq. 1) fitted with the curve parameters obtained from the appropriate positive control. EEQ values of the samples were corrected for background values in the negative control (1.28 $\pm 0.18 \mathrm{ng} / \mathrm{lEEQ}, n=226)$ and dilution factor (1.6).

$$
\begin{aligned}
\log \mathrm{EEQ}= & \log \mathrm{EC}_{50} \\
& -\left(\frac{(\log ([\text { top }- \text { bottom }] /[\text { corrected OD }- \text { bottom }]-1))}{\text { hillslope }}\right)
\end{aligned}
$$

\subsection{Reproduction test with Potamopyrgus antipodarum}

The test was conducted with the following specifications: All bottles were rinsed three times with ultrapure water and filled with $700 \mathrm{ml}$ defined culturing water $(\mathrm{pH} 8.0 \pm 0.5$, conductivity $770 \pm 100 \mu \mathrm{S} / \mathrm{cm})$. One hundred individuals of $P$. antipodarum (from a laboratory stock consisting exclusively of parthenogenetic females, see Schmitt et al. 2008) were inserted in each bottle. Borosilicate Erlenmeyer flasks with $700 \mathrm{ml}$ culturing water served as a negative solvent control $(0.0014 \% \quad v / v$ ethanol, $n=3) ; 17 \alpha$-ethinylestradiol (EE2, CAS 57-63-6) was used as positive control at a nominal concentration of $25 \mathrm{ng} / 1$ (in $0.0014 \% \mathrm{v} / \mathrm{v}$ ethanol, $n=3)$. The test was conducted under defined conditions $\left(15 \pm 1{ }^{\circ} \mathrm{C}\right.$, constant aeration, $16 / 8 \mathrm{~h}$ light/dark rhythm, random placement of replicates). $P$. antipodarum were fed every 4 to 5 days with $0.2 \mathrm{mg}$ TetraPhyll ${ }^{\circledR}$ per replicate. At the same time, all vessels were cleaned. A maximum mortality of $5 \%$ was observed at the end of the experiment.

In each replicate, 20 mudsnails were investigated for parthenogenetic production of embryos after 14, 28, and 56 days following a relaxation in $2.5 \% \mathrm{w} / \mathrm{v}$ magnesium chloride as reported previously (Duft et al. 2003b; Jobling et al. 2004). The total number of embryos per female after 56 days exposure proved to be a robust parameter for assessing endocrine disruptive effects in vivo.

\subsection{Statistical analysis}

Data analysis was performed using GraphPad Prism ${ }^{\circledR} 5.0$ (GraphPad Software, Inc., San Diego, USA). Nonparametric Mann-Whitney tests (two-tailed) were applied to compare the medians of data sets. In case of YES, data outliners were detected using Grubb's test $(p<0.05)$ and excluded. All presented data comprise of mean \pm standard error of the mean (SEM).

\section{Results}

\subsection{Yeast estrogen screen}

Screening of mineral water samples with the YES revealed a significantly elevated estrogenic activity in 12 of 20 brands (Fig. 1). Results were consistent for the three independent replicates per brand as well as for the three independent experiments performed. Average estrogenic potencies of the individual brands expressed in concen-

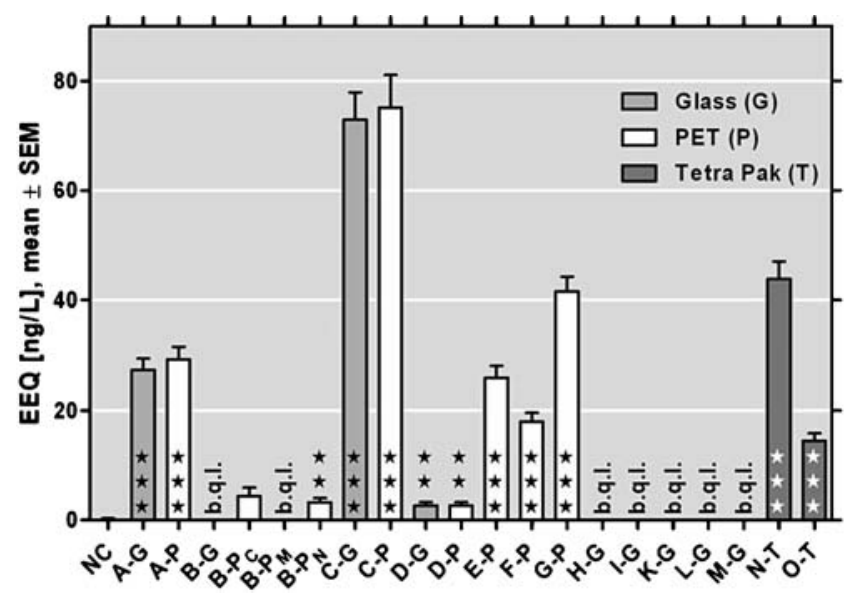

Fig. 1 Estrogenic potencies of mineral water expressed as estradiol equivalent concentrations ( $E E Q)$ measured with the yeast estrogen screen. Mineral water from three individual bottles of several brands $(A-O)$ were tested in three independent experiments (each sample in eight replicates). Negative control ( $N C), n=226$; water samples, $n=65$ to 75 . b.q.l. below quantification limit, double stars $p<0.01$ and triple stars $p<0.001$ as determined by Mann-Whitney test 
trations equivalent to $17 \beta$-estradiol (EEQ) ranged from below quantification limit (seven brands) to a maximum of $75.2 \pm 5.95 \mathrm{ng} / \mathrm{l}$ EEQ (brand C-P, $n=67$ ). The calculated average estrogenic burden of all samples was $18.0 \pm$ $0.80 \mathrm{ng} / 1$ EEQ $(n=1363)$. Furthermore, we detected a significantly increased hormonal activity in 33\% of all mineral water samples bottled in glass (three of nine brands). Compared to that, $78 \%$ of the waters from PET bottles (seven of nine brands) and both samples bottled in Tetra Pak were estrogen positive.

To evaluate the influence of the packaging material directly, we analyzed four mineral waters that originated from the same source (A-D) but were bottled in both glass and plastic. Apart from source D, mineral waters purchased in glass bottles were less estrogenic than the corresponding samples in PET bottles (Table 1). Water produced by spring $\mathrm{B}$ is available in three different plastic bottles $\left(\mathrm{B}-\mathrm{P}_{\mathrm{C}} / \mathrm{M}_{\mathrm{N}}\right)$. Estrogenic activity was not detectable in samples taken from glass bottles (B-G) and one sort of PET bottle (B-P $\left.\mathrm{P}_{\mathrm{M}}\right)$ that is returnable and is cleaned and filled several times. In contrast, the same water is estrogenic when supplied in oneway containers $\left(\mathrm{B}-\mathrm{P}_{\mathrm{C}} / \mathrm{N}\right)$. The same phenomenon is observed in case of spring D: Again, estrogenic activity in water from multi-use PET bottles (D-P) is not elevated compared to samples from the same bottler purchased in glass packaging (D-G).

\subsection{Reproduction test with Potamopyrgus antipodarum}

P. antipodarum responds highly sensitively to estrogens: After 56 days of exposure to $25 \mathrm{ng} / \mathrm{l}$ ethinylestradiol (positive control), the reproductive output of mudsnails (embryos per female) was more than doubled $(211 \pm 12.6 \%)$ compared to the negative control group $(100 \pm 11.6 \%)$. Culturing of $P$. antipodarum in water bottles filled with defined culturing water led to a significant increase of reproduction $(139.4 \pm 13.9 \%$ to $222 \pm 12.9 \%)$ in all PET brands of vessels (Fig. 2). In contrast, embryo production by mudsnails cultured in glass mineral water bottles was slightly but not significantly enhanced $(108.11 \pm 14.3 \%$ to $131.3 \pm 14.5 \%)$. Reproduction of $P$. antipodarum bred in two brands of plastic bottles (B-P $\mathrm{P}_{\mathrm{M}}$ and E-P, see Fig. 2) increased only moderately to $140 \%$. Interestingly, we also did not detect estrogenic activity in mineral water from the multi-use PET bottles of brand B (B- $\mathrm{P}_{\mathrm{M}}$, see Fig. 1). Vice versa, reproduction of $P$. antipodarum in brand $\mathrm{D}$ PET vessels (D-P, also reusable) increased significantly to $220 \pm$ $12.9 \%$ (see Fig. 2), whereas in the YES, the mineral water itself (D-P, see Fig. 1) did not contain higher estrogenicity when compared to the corresponding glass bottles (D-G).

Simultaneously, the estrogenic potency of water samples taken from all bottles was investigated in vitro with the YES. EEQ regularly recorded over the test period were
Table 1 Properties of the mineral water brands tested in the yeast estrogen screen

b.q.l. below quantification limit

\begin{tabular}{|c|c|c|c|c|c|c|}
\hline \multirow[t]{2}{*}{ Brand } & \multirow[t]{2}{*}{ Material } & \multirow[t]{2}{*}{ Use } & \multirow[t]{2}{*}{ Volume (1) } & \multicolumn{3}{|c|}{ Estrogenic activity, EEQ (ng/l) } \\
\hline & & & & Mean & SEM & $n$ \\
\hline $\mathrm{A}-\mathrm{G}$ & Glass & Reusable & 1 & 27.5 & 2.04 & 67 \\
\hline $\mathrm{A}-\mathrm{P}$ & PET & Non-reusable & 1.5 & 29.4 & 2.31 & 71 \\
\hline$B-G$ & Glass & Reusable & 0.7 & b.q.1. & - & 66 \\
\hline $\mathrm{B}-\mathrm{P}_{\mathrm{C}}$ & PET & Non-reusable & 0.5 & 4.38 & 1.55 & 69 \\
\hline $\mathrm{B}-\mathrm{P}_{\mathrm{M}}$ & PET & Reusable & 1 & b.q.1. & - & 70 \\
\hline $\mathrm{B}-\mathrm{P}_{\mathrm{N}}$ & PET & Non-reusable & 1.5 & 3.23 & 0.82 & 70 \\
\hline $\mathrm{C}-\mathrm{G}$ & Glass & Reusable & 1 & 73.0 & 4.99 & 67 \\
\hline $\mathrm{C}-\mathrm{P}$ & PET & Non-reusable & 1.5 & 75.2 & 5.95 & 67 \\
\hline $\mathrm{D}-\mathrm{G}$ & Glass & Reusable & 0.7 & 2.64 & 0.65 & 69 \\
\hline D-P & PET & Reusable & 1 & 2.65 & 0.64 & 69 \\
\hline $\mathrm{E}-\mathrm{P}$ & PET & Non-reusable & 1.5 & 26.1 & 2.12 & 68 \\
\hline $\mathrm{F}-\mathrm{P}$ & PET & Reusable & 1.5 & 18.0 & 1.57 & 68 \\
\hline $\mathrm{G}-\mathrm{P}$ & PET & Non-reusable & 0.5 & 41.6 & 2.73 & 68 \\
\hline $\mathrm{H}-\mathrm{G}$ & Glass & Reusable & 0.7 & b.q.1. & - & 71 \\
\hline $\mathrm{I}-\mathrm{G}$ & Glass & Reusable & 0.75 & b.q.1. & - & 69 \\
\hline $\mathrm{K}-\mathrm{G}$ & Glass & Reusable & 0.7 & b.q.1. & - & 69 \\
\hline $\mathrm{L}-\mathrm{G}$ & Glass & Reusable & 0.75 & b.q.1. & - & 66 \\
\hline $\mathrm{M}-\mathrm{G}$ & Glass & Reusable & 0.7 & b.q.1. & - & 66 \\
\hline $\mathrm{N}-\mathrm{T}$ & Tetra Pak & Non-reusable & 1 & 43.9 & 3.22 & 68 \\
\hline $\mathrm{O}-\mathrm{T}$ & Tetra Pak & Non-reusable & 2 & 14.5 & 1.35 & 65 \\
\hline
\end{tabular}




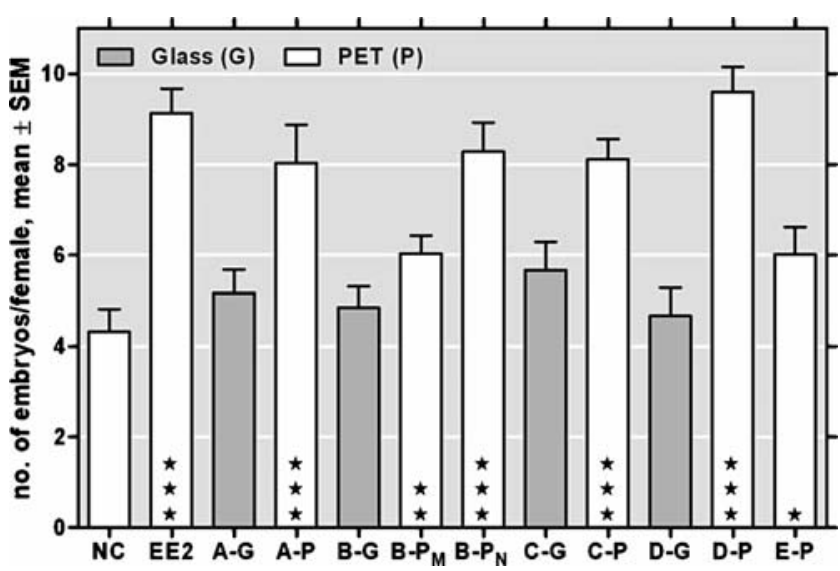

Fig. 2 Number of embryos produced by Potamopyrgus antipodarum after a 56-day period of culturing in glass and plastic bottles (three replicates per brand with 20 snails each). Negative control (NC), positive control (EE2), and samples, $n=60$. Single star $p<0.05$, double star $p<0.01$, and triple stars $p<0.001$ as determined by MannWhitney test

integrated and compared to the number of embryos produced in the same bottles. The resulting correlation (Spearman, $p=0.0075, r_{\mathrm{s}}=0.479,30$ data pairs) indicates that, in bottles with high estrogenic potency in vitro, reproduction of mudsnails was enhanced.

\section{Discussion}

The presence of endogenous estrogenic compounds in food is well documented in cases concerned with phytoestrogens and steroid hormones (Daxenberger et al. 2001; Fritsche and Steinhart 1999). Furthermore, the contamination of foodstuff with well-known EDCs like bisphenol A, phthalates, and alkylphenols is confirmed analytically (McNeal et al. 2000). Yet, only limited data exists on the total estrogenic burden of edibles, integrating known and unidentified EDCs as well as potential mixture effects. Therefore it seems justifiable to put the estrogenic potencies measured in mineral water in context with endogenous estrogens found in food and beverages.

Hartmann et al. (1998) proposed that dairy products are the main source for steroidal estrogens and calculated a total daily intake of 80-100 ng estrogens per day for adults. Based on our data, a theoretical daily consumption of 31 mineral water (drinking water required to maintain hydration, Howard and Bartram 2003) would result in a mean total intake of 54 ng EEQ per day. In a worst case scenario (3 1 of brand C-P), the total daily intake would increase to 226 ng EEQ per day, exceeding the intake of estrogens naturally found in food (Hartmann et al. 1998) by more than $100 \%$. In a more recent study, Courant et al. (2007) analytically determined concentrations of $23 \mathrm{ng} / \mathrm{l} 17 \mathrm{~B}-$ estradiol in milk. The concentration of natural estrogen in milk is comparable to the mean hormonal potency we measured in 20 brands of mineral water (18 ng/l EEQ) and three times lower than the maximal EEQ detected in one brand of water (75 ng/l EEQ). Therefore, consumption of mineral water results in a human exposure to xenoestrogens with at least the same hormonal potency as steroidal estrogens naturally occurring in food.

Few authors utilized the YES or other in vitro assays to assess the total estrogenicity of beverages or foodstuff. Klinge et al. (2003) detected a maximum $84 \mathrm{ng} / \mathrm{l} \mathrm{EEQ}$ in red wine. Promberger et al. (2001) calculated 23-41 ng/l EEQ for beer, a result that was confirmed by Takamura-Enya et al. (2003), who detected an estrogenic potency of approximately $30 \mathrm{ng} / \mathrm{l}$ EEQ in beer; extracts from soy based food (miso, tofu, and soy sauce) and coffee also contained EEQ in low nanogram per liter range. The range of estrogenic burden we found in several brands of mineral water is comparable to the hormonal activity of wine, beer, and soy products, detected with the same in vitro assay. Again, the distinction is that the abovementioned studies confirmed naturally occurring phytoestrogens as an endogenous source of estrogenicity, whereas mineral water does not contain phytoestrogens.

Using a well-established in vitro assay, we provide first quantitative data on the estrogenic burden of commercially available mineral water. The high abundance $(60 \%$ of all samples) and potency (mean of $18 \mathrm{ng} / \mathrm{l} \mathrm{EEQ)} \mathrm{of} \mathrm{estro-}$ genicity clearly demonstrates that food obviously lacking endogenous estrogens significantly contributes to human exposure with estrogenic compounds. In contrast to estrogens naturally occurring in foodstuff and beverages, the sources of estrogens in water must be exogenous.

From the in vitro data shown in this study, we conclude that there are three sources for the estrogenic contamination of mineral water: First of all, the water may be estrogenic by itself, implying that the untreated groundwater from the spring contains substances with hormonal potency. So far, there is no evidence for the presence of intrinsic estrogenicity in water. Another source of hormonal activity in groundwater may be the reflux of synthetic estrogens like $17 \alpha$-ethinylestradiol and other pharmaceuticals from wastewater discharge. Although shown for surface water (Cargouet et al. 2004), no clear evidence for the entry of $17 \alpha$-ethinylestradiol in groundwater is available up to now.

A second source of the estrogenic activity of mineral water is the production process. Especially with regard to the water samples from springs A and C (see Fig. 1), which contained a conspicuously high estrogenic burden independent of the packaging material, a production-related contamination with xenoestrogens seems probable. The presence of several phthalate plasticizers in citrus essential oils, for example, was attributed to new plastic components used in the production (Di Bella et al. 2001). Another source 
might be residual detergents and disinfectants used for cleaning the filling system. Guenther et al. (2002) detected estrogenic nonylphenols in a broad range of foodstuff and concluded that part of it might originate from nonionic surfactants used in cleaning agents.

As a third source of xenoestrogens in mineral water, we propose the migration of EDCs from the packaging material. The analysis of data according to the packaging material (Fig. 3a) demonstrates that the estrogenic contamination of mineral water bottled in plastic (PET and Tetra Pak) is significantly higher compared to that of water bottled in glass $(p<0.001)$. This implies an influence of the packaging material: Substances with estrogenic potency leaching from the plastic packaging could contribute to the hormonal burden of mineral water reported in this study. With regard to the four mineral waters that originated from the same source but were purchased in glass and plastic (AD), the lower estrogenicity of the appropriate glass bottled waters (apart from spring D, see Fig. 1) supports our hypothesis of estrogenic contamination by the plastic packaging. The estrogenic burden of water purchased in Tetra Pak has to be interpreted tentatively since only two brands were examined due to low market shares. Again, higher contamination compared to samples from glass bottles (see Fig. 3 a, $p<0.001$ ) could be attributed to the migration of EDCs from the inner lining of the Tetra Pak packaging, which consists of a polyethylene plastic film.

To exclude the influence of the first two sources of xenoestrogens in mineral water (contamination by spring or production) and to exclusively characterize the estrogenic potency emerging from the packaging material, we conducted a reproduction test with the New Zealand mudsnail $P$. antipodarum. In this study, the prosobranch snail acts as a sentinel for xenoestrogens. In the current experiment, this is

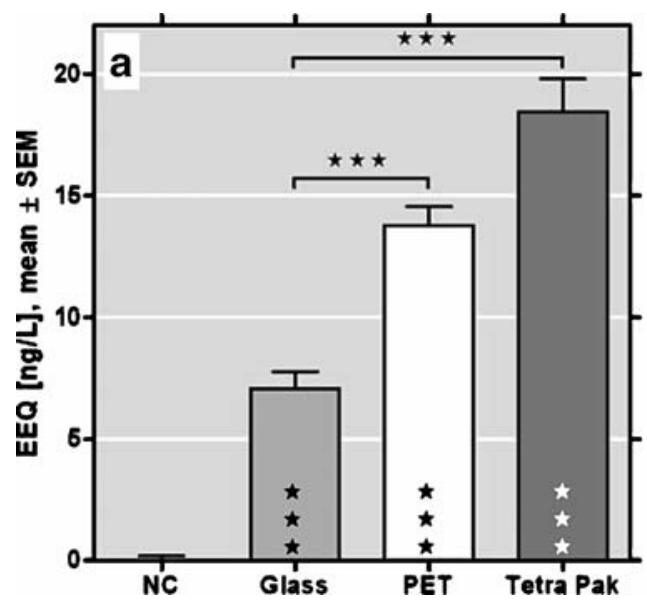

Fig. 3 Estrogenic potencies of mineral water in vitro (a) and reproduction of Potamopyrgus antipodarum (b). Data were pooled according to packaging material. a Estrogenic potencies (EEQ) measured with the yeast estrogen screen. Negative control $(N C), n=$ 226; glass, $n=610$; PET, $n=620$; Tetra Pak, $n=133$. b Number of documented by the positive control with the synthetic estrogen $17 \alpha$-ethinylestradiol (EE2). After 56 days of exposure to $25 \mathrm{ng} / \mathrm{lEE} 2$, the reproduction of $P$. antipodarum, expressed as number of embryos produced per female, was more than doubled compared to control animals (see Fig. 2).

Other studies emphasize that the sensitivity of $P$. antipodarum is not limited to EE2 but applies for a wider range of EDCs: Jobling et al. (2004) observed effects of EE2, bisphenol A, and octylphenol on P. antipodarum that were very similar to the ones shown in this study. Duft et al. (2003a,b) provide data on xenoestrogens (bisphenol A, octylphenol, and nonylphenol) as well as on the xenoandrogens triphenyltin and tributyltin. Although the mechanism, through which EDCs act on mollusks, is not yet elucidated (Köhler et al. 2007), many gastropod species are known to be susceptible to EDC exposure (Oehlmann et al. 2006; Oehlmann et al. 2007).

In the current experiment, breeding of $P$. antipodarum in several brands of glass bottles resulted in a slightly enhanced production of embryos compared to the negative control group (see Fig. 2), which consisted of inert Borosilicate glass vessels. Since this difference is not statistically significant, there is little evidence for the occurrence of xenoestrogens migrating from the glass material into the culturing water. In contrast, reproductive patterns of specimens kept in PET bottles changed distinctly during the test period: Females cultured in four brands of plastic bottles produced approximately twice as much embryos compared to the negative control $(90-120 \%$, see Fig. 2). Again, analysis of data according to the packaging material reveals a significantly enhanced progeny of $P$. antipodarum from the PET group compared to specimens from the glass group and negative control $(p<0.001$, Fig. 3b). Taking into account that the same culturing water

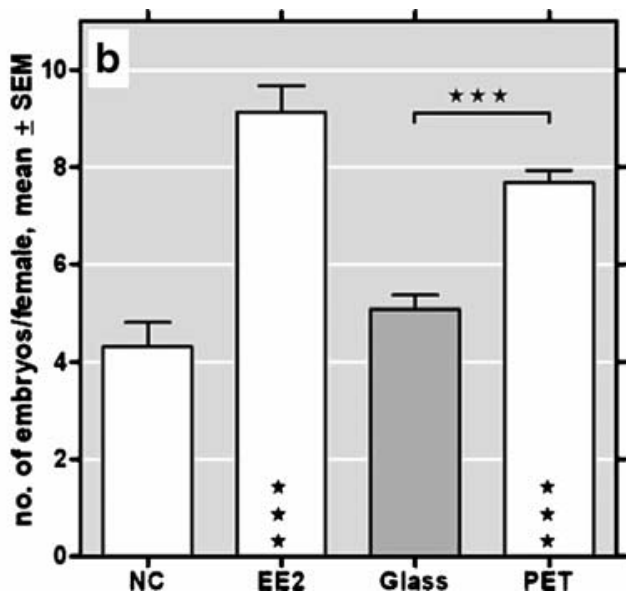

embryos produced by Potamopyrgus antipodarum after a 56-day period of culturing in glass and plastic bottles. Negative control (NC) and positive control (EE2), $n=60$; glass, $n=240$; PET, $n=360$. Triple stars $p<0.001$ as determined by Mann-Whitney test 
was filled in all vessels at the beginning of the experiment, it is obvious that the observed effects can only be attributed to xenoestrogen leaching from these plastic bottles. Moreover, the compounds released by the PET material were potent to trigger estrogenic effects in vivo similar to those of EE2 at a concentration of $25 \mathrm{ng} / \mathrm{l}$.

A similar observation was made by Howdeshell et al. (2003): Uterine weight of prepubertal female mice housed in cages made of polycarbonate increased by $16 \%$ compared to mice from polypropylene cages. Although this estrogenic effect was not statistically significant, it was linked to the exposure to bisphenol A leaching from polycarbonate cages. In contrast to polycarbonates, PET is believed to be free from bisphenol A. Still, Toyo'oka and Oshige (2000) detected 3-10 ng/l bisphenol A in several brands of mineral water from PET bottles but did not confirm its origin. These results were not confirmed by Shao et al. (2005), who could not detect bisphenol A in different beverages from plastic bottles (material not stated) including mineral water. Nonetheless, estrogenic nonylphenols were detected in both studies in concentrations from 16-465 ng/l. The leaching of $p$-nonylphenol from plastic tubes used in the laboratory was first described by Soto et al. (1991). Because bisphenol A and nonylphenols are ubiquitous, we cannot exclude their presence in mineral water.

The same is true for endocrine-disrupting phthalates: Despite some claims that phthalates are not used in manufacturing PET food packaging (Enneking 2006), Kim et al. (1990) extracted several phthalates from PET water bottles (among them DEHP, DBP, and DEP). The migration of DEHP from PET into mineral water was reported by Biscardi et al. (2003). Casajuana and Lacorte (2003) monitored several phthalates in mineral water and found increased concentrations of DMP, DEP, DBP, and DEHP after storing water in PET bottles for 10 weeks. In a recent study, Montuori et al. (2008) compared mineral waters bottled in glass and PET and detected significantly higher amounts of phthalates (DMP, DEP, DiBP, DBP, and DEHP) in plastic bottled water. The sum of studied compounds was thus 12 times higher in water from PET bottles compared to samples from glass bottles. Taken together, there is good analytical evidence for the migration of certain phthalates from PET food packaging materials, some of them well-known xenoestrogens (Jobling et al. 1995). However, the estrogenicity reported in this study might also arise from unexpected compounds: Shotyk et al. (2006) found antimony in up to 30 times higher concentrations in mineral water from PET compared to glass bottles and confirmed its leaching from PET (Shotyk and Krachler 2007), in whose manufacturing antimony trioxide is used as catalyst. The maximum concentrations detected in mineral water $(1-2 \mu \mathrm{g} / \mathrm{l})$ have been shown to exhibit estrogenic activity in vitro (Choe et al. 2003).
The analytical data from the literature suggest that the observed estrogenic effects reported in this paper cannot be attributed to one of the compounds alone, owing to the fact that individual concentrations are too low to be effective. Since the assays used in this study integrate all xenoestrogens present in the samples, we propose that there are either potent estrogenic mixtures causing the in vitro and in vivo effects (Rajapakse et al. 2002; Silva et al. 2002) or so far unidentified compounds with strong estrogenic potency.

\section{Conclusions}

Our findings provide first evidence for a broad contamination of mineral water with xenoestrogens, typically in the range of 2-40 ng/l EEQ with maximum values of $75 \mathrm{ng} / \mathrm{l}$ EEQ. Consumption of commercially bottled mineral water may therefore contribute to the overall exposure of humans with endocrine disruptors. Moreover, it is probable that this estrogenic contamination originates from plastic food packaging materials because mineral water bottled in PET and Tetra Pak is more estrogenic than water bottled in glass. This gives rise to the assumption that additives such as plasticizers or catalysts migrate from the plastic packaging into the foodstuff. Though yet unidentified, these substances act as functionally active estrogens in vitro on the human estrogen receptor alpha and in vivo in a molluskan model. Therefore, we may have identified just the tip of the iceberg in that plastic packaging may be a major source for xenohormone contamination of many other edibles. Still, this study was not designed to evaluate whether the consumption of plastic packed nourishments comprehends the risk of endocrine disruptive effects in humans. It instead provides an insight into the potential exposure to EDCs due to unexpected sources of contamination.

Acknowledgment This work was supported by the German Federal Environment Agency (206 67 448/04). We thank Prof. Dr. F. vom Saal, Dr. U. Schulte-Oehlmann, P. Di Benedetto, and M. Hess for the positive input to the project and comments on this manuscript and Dr. S. Jobling (Brunel University London) for providing the YES strain.

Open Access This article is distributed under the terms of the Creative Commons Attribution Noncommercial License which permits any noncommercial use, distribution, and reproduction in any medium, provided the original author(s) and source are credited.

\section{References}

Anway MD, Cupp AS, Uzumcu M, Skinner MK (2005) Epigenetic transgenerational actions of endocrine disruptors and male fertility. Science 308:1466-1469 
Biles JE, McNeal TP, Begley TH, Hollifield HC (1998) Determination of bisphenol A in reusable polycarbonate food-contact plastics and migration to food-simulating liquids. J Agric Food Chem 46:2894-2894

Biscardi D, Monarca S, De Fusco R, Senatore F, Poli P, Buschini A, Rossi C, Zani C (2003) Evaluation of the migration of mutagens/ carcinogens from PET bottles into mineral water by Tradescantial micronuclei test, Comet assay on leukocytes and GC/MS. Sci Total Environ 302:101-108

Cargouet M, Perdiz D, Mouatassim-Souali A, Tamisier-Karolak S, Levi Y (2004) Assessment of river contamination by estrogenic compounds in Paris area (France). Sci Total Environ 324:55-66

Casajuana N, Lacorte S (2003) Presence and release of phthalic esters and other endocrine disrupting compounds in drinking water. Chromatographia 57:649-655

Choe SY, Kim SJ, Kim HG, Lee JH, Choi Y, Lee H, Kim Y (2003) Evaluation of estrogenicity of major heavy metals. Sci Total Environ 312:15-21

Colborn T, Dumanoski D, Myers JP (1996) Our stolen future: are we threatening our fertility, intelligence and, survival? A scientific detective story. Dutton, New York

Colón I, Caro D, Bourdony CJ, Rosario O (2000) Identification of phthalate esters in the serum of young Puerto Rican girls with premature breast development. Environ Health Perspect 108:895900

Courant F, Antignac JP, Maume D, Monteau F, Andre F, Le Bizec B (2007) Determination of naturally occurring oestrogens and androgens in retail samples of milk and eggs. Food Addit Contam 24:1358-1366

Damstra T, Barlow S, Bergman A, Kavlock R, Van Der Kraak G (2002) Global Assessment of the State-of-the-Science of Endocrine Disruptors. WHO publication no. WHO/PCS/EDC/02.2. World Health Organisation, Geneva, Switzerland

Damstra T (2003) Endocrine disrupters: the need for a refocused vision. Toxicol Sci 74:231-232

Daxenberger A, Ibarreta D, Meyer HHD (2001) Possible health impact of animal oestrogens in food. Hum Reprod Update 7:340 355

Di Bella G, Saitta M, Lo Curto S, Salvo F, Licandro G, Dugo G (2001) Production process contamination of citrus essential oils by plastic materials. J Agric Food Chem 49:3705-3708

Duft M, Schulte-Oehlmann U, Weltje L, Tillmann M, Oehlmann J (2003a) Stimulated embryo production as a parameter of estrogenic exposure via sediments in the freshwater mudsnail Potamopyrgus antipodarum. Aquat Toxicol 64:437-449

Duft M, Schulte-Oehlmann U, Tillmann M, Markert B, Oehlmann J (2003b) Toxicity of triphenyltin and tributyltin to the freshwater mudsnail Potamopyrgus antipodarum in a new sediment biotest. Environ Toxicol Chem 22:145-152

Enneking PA (2006) Phthalates not in plastic food packaging. Environ Health Perspect 114:A89-A90

Fankhauser-Noti A, Biedermann-Brem S, Grob K (2006) PVC plasticizers/additives migrating from the gaskets of metal closures into oily food: Swiss market survey June 2005. Eur Food Res Technol 223:447-453

Fritsche S, Steinhart H (1999) Occurrence of hormonally active compounds in food: a review. Eur Food Res Technol 209:153-179

Guenther K, Heinke V, Thiele B, Kleist E, Prast H, Raecker T (2002) Endocrine disrupting nonylphenols are ubiquitous in food. Environ Sci Technol 36:1676-1680

Hartmann S, Lacorn M, Steinhart H (1998) Natural occurrence of steroid hormones in food. Food Chem 62:7-20

Hotchkiss AK, Rider CV, Blystone CR, Wilson VS, Hartig PC, Ankley GT, Foster PM, Gray CL, Gray LE (2008) Fifteen years after 'Wingspread'-Environmental endocrine disrupters and human and wildlife health: where we are today and where we need to go. Toxicol Sci 105:235-259

Howard G, Bartram J (2003) Domestic water quantity, service level and health. World Health Organisation, Geneva

Howdeshell KL, Hotchkiss AK, Thayer KA, Vandenbergh JG, vom Saal FS (1999) Environmental toxins - exposure to bisphenol A advances puberty. Nature 401:763-764

Howdeshell KL, Peterman PH, Judy BM, Taylor JA, Orazio CE, Ruhlen RL, vom Saal FS, Welshons WV (2003) Bisphenol A is released from used polycarbonate animal cages into water at room temperature. Environ Health Perspect 111:1180-1187

Jobling S, Reynolds T, White R, Parker MG, Sumpter JP (1995) A variety of environmentally persistent chemicals, including some phthalate plasticizers, are weakly estrogenic. Environ Health Perspect 103:582-587

Jobling S, Casey D, Rogers-Gray T, Oehlmann J, Schulte-Oehlmann U, Pawlowski S, Baunbeck T, Turner AP, Tyler CR (2004) Comparative responses of molluscs and fish to environmental estrogens and an estrogenic effluent. Aquat Toxicol 66:207-222

Kim H, Gilbert SG, Johnson JB (1990) Determination of potential migrants from commercial amber polyethylene terephthalate bottle wall. Pharm Res 7:176-179

Klinge CM, Risinger KE, Watts MB, Beck V, Eder R, Jungbauer A (2003) Estrogenic activity in white and red wine extracts. J Agric Food Chem 51:1850-1857

Köhler HR, Kloas W, Schirling M, Lutz I, Reye AL, Langen JS, Triebskorn R, Nagel R, Schonfelder G (2007) Sex steroid receptor evolution and signalling in aquatic invertebrates. Ecotoxicology 16:131-143

Lau OW, Wong SK (2000) Contamination in food from packaging material. J Chromatogr A 882:255-270

McNeal TP, Biles JE, Begley TH, Craun JC, Hopper ML, Sack CA (2000) Determination of suspected endocrine disruptors in foods and food packaging. In: Analysis of Environmental Endocrine Disruptors, Vol. 747, pp 33-52. American Chemical Society, Washington

Montuori P, Jover E, Morgantini M, Bayona JM, Triassi M (2008) Assessing human exposure to phthalic acid and phthalate esters from mineral water stored in polyethylene terephthalate and glass bottles. Food Addit Contam 25:511-518

Oehlmann J, Schulte-Oehlmann U, Bachmann J, Oetken M, Lutz I, Kloas W, Ternes TA (2006) Bisphenol A induces superfeminization in the ramshorn snail Marisa cornuarietis (Gastropoda: Prosobranchia) at environmentally relevant concentrations. Environ Health Perspect 114:127-133

Oehlmann J, Di Benedetto P, Tillmann M, Duft M, Oetken M, SchulteOehlmann U (2007) Endocrine disruption in prosobranch molluscs: evidence and ecological relevance. Ecotoxicology 16:29-43

Promberger A, Dornstauder E, Fruhwirth C, Schmid ER, Jungbauer A (2001) Determination of estrogenic activity in beer by biological and chemical means. J Agric Food Chem 49:633-640

Rajapakse N, Silva E, Kortenkamp A (2002) Combining xenoestrogens at levels below individual no-observed-effect concentrations dramatically enhances steroid hormone action. Environ Health Perspect 110:917-921

Routledge EJ, Sumpter JP (1996) Estrogenic activity of surfactants and some of their degradation products assessed using a recombinant yeast screen. Environ Toxicol Chem 15:241-248

Rutishauser BV, Pesonen M, Escher BI, Ackermann GE, Aerni HR, Suter MJF, Eggen RIL (2004) Comparative analysis of estrogenic activity in sewage treatment plant effluents involving three in vitro assays and chemical analysis of steroids. Environ Toxicol Chem 23:857-864

Safe SH (2000) Endocrine disruptors and human health - is there a problem? An update. Environ Health Perspect 108:487-493 
Safe SH (2005) Clinical correlates of environmental endocrine disruptors. Trends Endocrinol Metab 16:139-144

Schettler T (2006) Human exposure to phthalates via consumer products. Int J Androl 29:134-139

Schmitt C, Oetken M, Dittberner O, Wagner M, Oehlmann J (2008) Endocrine modulation and toxic effects of two commonly used UV screens on the aquatic invertebrates Potamopyrgus antipodarum and Lumbriculus variegatus. Environ Pollut 152:322-329

Shao B, Han H, Hu JY, Zhao J, Wu GH, Xue Y, Ma YL, Zhang SJ (2005) Determination of alkylphenol and bisphenol A in beverages using liquid chromatography/electrospray ionization tandem mass spectrometry. Anal Chim Acta 530:245-252

Sharpe RM (2003) The 'oestrogen hypothesis'-where do we stand now. Int J Androl 26:2-15

Shotyk W, Krachler M, Chen B (2006) Contamination of Canadian and European bottled waters with antimony from PET containers. J Environ Monit 8:288-292

Shotyk W, Krachler M (2007) Contamination of bottled waters with antimony leaching from polyethylene terephthalate (PET) increases upon storage. Environ Sci Technol 41:1560-1563

Silva E, Rajapakse N, Kortenkamp A (2002) Something from 'nothing'-eight weak estrogenic chemicals combined at concentrations below NOECs produce significant mixture effects. Environ Sci Technol 36:1751-1756
Soto AM, Justicia H, Wray JW, Sonnenschein C (1991) Paranonyl-phenol - an estrogenic xenobiotic released from modified polystyrene. Environ Health Perspect 92:167-173

Swan SH, Main KM, Liu F, Stewart SL, Kruse RL, Calafat AM, Mao CS, Redmon JB, Ternand CL, Sullivan S, Teague JL (2005) Decrease in anogenital distance among male infants with prenatal phthalate exposure. Environ Health Perspect 113:1056-1061

Takamura-Enya T, Ishihara J, Tahara S, Goto S, Totsuka Y, Sugimura T, Wakabayashi K (2003) Analysis of estrogenic activity of foodstuffs and cigarette smoke condensates using a yeast estrogen screening method. Food Chem Toxicol 41:543-550

Toyo'oka T, Oshige Y (2000) Determination of alkylphenols in mineral water contained in PET bottles by liquid chromatography with coulometric detection. Anal Sci 16:1071-1076

vom Saal FS, Hughes C (2005) An extensive new literature concerning low-dose effects of bisphenol A shows the need for a new risk assessment. Environ. Health Perspect 113:926-933

Waring RH, Harris RM (2005) Endocrine disrupters: a human risk. Mol Cell Endocrinol 244:2-9

Zygoura PD, Paleologos EK, Riganakos KA, Kontominas MG (2005) Determination of diethylhexyladipate and acetyltributylcitrate in aqueous extracts after cloud point extraction coupled with microwave assisted back extraction and gas chromatographic separation. J Chromatogr A 1093:29-35 